\title{
SEM/PLS Application for Analysis of Factors Affecting Customer's Decision in Using Mobile Banking at Bank Mandiri Medan Gunung Karakatau Sub-Branch
}

\author{
Amy Aulia Purba ${ }^{1}$, Isfenti Sadalia ${ }^{2}$, Chairul Muluk ${ }^{2}$ \\ ${ }^{1,2}$ Master of Management Study Program on Postgraduate School of University of Sumatera Utara \\ Corresponding Author: Amy Aulia Purba
}

DOI: https://doi.org/10.52403/ijrr.20220147

\begin{abstract}
This study aims to examine the effect of perceived convenience, perceived usefulness, knowledge, risk perception, security and customer trust on the use of mobile banking at Bank Mandiri Medan Gunung Krakatau SubBranch. The number of respondents examined in this study were 150 respondents. All respondents are customers of Bank Mandiri Medan Gunung Krakatau Sub-Branch. This research uses a quantitative approach. The data in this study were obtained from the results of distributing questionnaires that had previously been through the trial phase and proved to be valid and reliable in measuring each research variable. The data in this study were analyzed using the Partial Least Square (PLS) analysis technique with the help of the Smartpls program. Based on the results of the analysis in this study, the results show that: (1) Perceptions of convenience, perceived benefits, perceived risk and trust can directly influence a customer's decision to use mobile banking, (2) Knowledge and security cannot directly influence the decision to use mobile banking; (3) knowledge can directly influence the decision to use mobile banking mediated by the perspective of benefits; (4) security may affect indirectly the decision to use mobile banking mediated by customer trust. The analysis also shows that $51.7 \%$ of decisions to use mobile banking for customers of Bank Mandiri Medan Gunung Krakatau Sub-Branch are influenced by perceptions of convenience, perceived benefits, knowledge, perceptions of risk, security and customer trust; $49.2 \%$
\end{abstract}

variance of customer perceptions of the benefits of mobile banking is influenced by perceptions of convenience and customer knowledge; $46.9 \%$ of customer confidence in mobile banking applications is influenced by customer risk perceptions of the use of mobile banking and where the system is in the mobile banking application.

Keywords: perceived ease, perceived benefits, knowledge, perceived risk, security, trust, use of mobile banking, Partial Least Square.

\section{BACKGROUND}

In the current era of globalization, business competition between companies is increasing both in the domestic and international markets. Companies that want to develop will try to create excellence both in the field of products, services and in the field of technology. In the current era, banking companies are moving more aggressively in an effort to improve and make it easier for everyone to make transactions. This causes companies in other service sectors to create corporate strategies so that they can be superior to their competitors. One of the strategies carried out is the revolution in the development of information and communication technology. The revolution in information and communication technology has made it easier for people to obtain information quickly and practically. According to Nasir 
and Yuslinaini (2017: 12) Information and communication technology that is developing rapidly has blurred regional boundaries because one region can be connected to other regions at the same time.

Rema and Setyohadi (2016) explain that the rapid development of information technology has a global impact on banking. One of the impacts is the introduction of mobile banking which is part of electronic commerce as the newest wireless banking information service offered by banks using technology found on smartphones to support the smoothness and ease of banking activities (Sulistiyarini, 2013). Through mobile banking, banks try to provide fast, easy, convenient, accessible services anywhere and anytime. With mobile banking services, checking account balances, monitoring deposit terms, checking credit card status and credit card payments, paying electricity bills, telephone and other transactions will be easier to do (Pratiwi, 2012).

Based on the Transaction Volume and Total Transactions of Mobile Banking Nationally, it can be seen that the Retail segment product that experienced the most significant growth in transaction volume was Livin by Mandiri at $43.24 \%$ in 2020 . Although the volume of transactions using mobile banking in Indonesia as a whole has increased, the number of customers who have activated mobile banking at Medan GunungKarakatau Sub-branch has experienced fluctuations. In June there were 112 people activated, in July there were 117 people, in August there were 96 people, in September there were 109 people, in October 81 people, in November 74 people and in December 87 people. The number of users of mobile banking should continue to increase every month. Especially considering the many benefits that customers get. One of them in terms of time and energy saved, mobile banking can be used anywhere and anytime as long as it is connected to a good internet network. But in fact this is not in line with the development of mobile banking users. This facility is not fully utilized by the Indonesian people (Tjini and Baridwan 2013:3).

There are several factors that must be considered by customers when they want to use mobile banking services or what is known as m-banking. The factors that influence the use of m-banking services such as perceptions of ease of use, perceptions of benefits, perceptions of risk, knowledge, trust and security. According to Nasri and Charfeddine (2012) explains that Perception of Ease of Use (Perception of ease of use) is a person's belief in which the use of a new system can be easily used and understood. The perception of ease of use is believed to have a strong influence on the formation of an individual's attitude in accepting a technology. The easier it is to learn and use it will increase customer interest in using mobile banking.

The results of research conducted by Amijaya (2010), Yanuardinda (2014) and Susanto (2013) proves that perceived ease of use has a significant effect on customer re-interest in using mobile banking. However, the results of this study are not consistent with research conducted by Habibi and Zaky (2015: 20) which shows that perceived ease of use has no effect on interest in using Islamic mobile banking.

According to Desmayanti (2012) in the research of Ni Putu Bella Novindra and Ni KetutRasmini (2017: 1123) explains that Benefit Perception is defined how the use of a new system can provide usefulness to its users. Perceived benefits, mobile banking services will be useful if the service is easy to understand and able to interact with users. The bank provides services such as checking balances, transfers between accounts, exchange rate information and so on in mobile banking with the aim of making transactions easier for customers. Benefits for customers include making work easier, increasing productivity, increasing effectiveness and improving job performance. 




Conceptual Framework

\section{Hypotheses}

H1:Perception of ease to use has a positive and significant effect on perception of benefits

$\mathrm{H} 2$ :Perception of ease to use has a positive and significant effect on decisions to use mobile banking

H3:Knowledge has a positive and significant effect on perception of benefits

$\mathrm{H} 4$ :Knowledge has a positive and significant effect on decisions to use mobile banking

H5:Perception of benefit has a positive and significant effect on decisions to use mobile banking

H6:Risk perception has a negative and significant effect on decisions to use mobile banking

H7:Risk perception has a negative and significant effect on trust

H8:Secutity has a positive and significant effect on decisions to use mobile banking H9:Secutity has a positive and significant effect on trust

H10:Trust has a positive and significant effect on decisions to use mobile banking

\section{RESEARCH METHOD}

This research conducted by field data research. Therefore, data collection from customers was carried out directly in the field by distributing questionnaires. This study discusses the factors that influence customer decisions in using mobile banking at Medan GunungKarakatau Sub-branch. The type of research used in this study is quantitative research. The population in this study is 10,000 customers at Bank Mandiri
Medan GunungKarakatau Sub-branch until 2021. Based on the population with an error rate that researchers use is $10 \%$, according to Bawono (2006: 29) the formula used to determine the number of samples is the formula from Slovin or as many as 150 people or with an error rate or error that is believed to be $8.1 \%$ of customers at PT Bank Mandiri in Karakatau Sub-branch. The data analysis technique in this study used Partial Least Square (PLS). PLS is a Structural Equation Modeling (SEM) equation model with an approach based on variance or component-based structural equation modeling, in data analysis using SmartPLS software.

\section{RESULT AND DISCUSSION Inner Model Test}

At the structural model testing stage, before testing the structural model, the feasibility of the model is first tested by looking at the $\mathrm{R}$ square value and the $\mathrm{Q}$ square model value.

Table 1: R Square

\begin{tabular}{ccc}
\hline & R Square & R Square Adjusted \\
\hline $\mathrm{X} 2$ & 0.498 & 0.492 \\
\hline $\mathrm{X} 5$ & 0.476 & 0.469 \\
\hline $\mathrm{Y}$ & 0.536 & 0.517 \\
\hline
\end{tabular}

Based on the results of the analysis in the table above, the $\mathrm{R}$ square value of the perceived benefit variable (X2) is 0.498 , the $\mathrm{R}$ square value of the trust construct (X5) is 0.476 and the $\mathrm{R}$ square value of the decision to use mobile banking (Y) is 0.536 , because the $\mathrm{R}$ square value is all endogenous variables have exceeded 0.33 then it can be stated that the model is in the moderate category when used to predict perceived benefits, customer trust and customer decisions to use mobile banking.




The value of Q square is categorized into 3 categories, namely small, medium and large, the value of Q square of 0.02 is declared small, the value of $Q$ square of 0.15 is declared moderate and the value of $\mathrm{Q}$ square of 0.35 is declared large.

The calculation of $\mathrm{Q}$ square in the table above shows that the value of $Q$ square of the construct of perceived benefits (X2) is 0.383 , the value of $\mathrm{Q}$ square of the trust construct (X5) is 0.408 and the $\mathrm{Q}$ square value of the decision construct to use mobile banking (Y) is 0.464 , because the value of $\mathrm{Q}$ square of both endogenous constructs has exceeded 0.35 , it can be concluded that the PLS model has high predictive relevance.

Based on the results of the evaluation of the feasibility of the model by looking at the values of $\mathrm{R}$ square and $\mathrm{Q}$ square of the model, it can be concluded that the structural model is suitable to be used to test the research hypothesis.

\section{Path Coefficient Evaluation and Direct Effect Test}

Table 3: Partial Effect Test Results

\begin{tabular}{|c|c|c|c|c|c|}
\hline & $\begin{array}{c}\text { Original } \\
\text { Sample } \\
\text { (0) }\end{array}$ & $\begin{array}{c}\text { Sample } \\
\text { Mean (M) }\end{array}$ & $\begin{array}{l}\text { Standard } \\
\text { Deviation } \\
\text { (STDEV) }\end{array}$ & $\begin{array}{c}\text { T Statistics } \\
(|0 / \mathrm{STDEV}|)\end{array}$ & P Values \\
\hline $\mathrm{X} 1->\mathrm{X} 2$ & 0.402 & 0.404 & 0.064 & 6.303 & 0.000 \\
\hline X1 -> Y & 0.208 & 0.217 & 0.086 & 2.433 & 0.008 \\
\hline X2 -> Y & 0.273 & 0.275 & 0.095 & 2.887 & 0.002 \\
\hline $\mathrm{X} 3->\mathrm{X} 2$ & 0.394 & 0.393 & 0.065 & 6.083 & 0.000 \\
\hline X3 -> Y & 0.068 & 0.069 & 0.094 & 0.730 & 0.233 \\
\hline X4 -> X5 & -0.174 & -0.175 & 0.078 & 2.220 & 0.013 \\
\hline X4 -> Y & -0.215 & -0.221 & 0.069 & 3.113 & 0.001 \\
\hline X5 -> Y & 0.197 & 0.192 & 0.108 & 1.826 & 0.034 \\
\hline X6 -> X5 & 0.697 & 0.694 & 0.038 & 18.302 & 0.000 \\
\hline X6 -> Y & 0.081 & 0.080 & 0.104 & 0.781 & 0.218 \\
\hline
\end{tabular}

Based on the results of testing the hypothesis above, the following test results are obtained:

\section{1) Line $X 1 \rightarrow X 2$}

In the path that shows the relationship between perceived convenience and perceived benefits (X1 X2), the $\mathrm{p}$ value obtained is 0.000 with a T statistic of 6.303 and a positive path coefficient of 0.402 . Because the path $\mathrm{p}$ value $<0.05$, T statistic $>1.65$ and the path coefficient is positive, it can be concluded that the perception of convenience has a positive and significant effect on the perception of benefits, this indicates that the higher the customer's perception of the ease of using mobile banking, the higher the customer's perception of the benefits of using mobile banking.

\section{2) Line $X 1 \rightarrow Y$}

In the path that shows the relationship between the perception of convenience and the decision to use mobile banking (X1 Y), the $\mathrm{p}$ value obtained is 0.008 with a $\mathrm{T}$ statistic of 2.433 and a positive path coefficient of 0.208 . Because the path $p$ value $<0.05$, $\mathrm{T}$ statistic $>1.65$ and the path coefficient is positive, it can be concluded that customer perceptions of the ease of use of mobile banking applications have a positive and significant effect on customer decisions to use mobile banking. The higher the customer's perception of the ease of use of the mobile banking application, the higher the customer's decision to use mobile banking.

\section{3) Line $X 3 \rightarrow X 2$}

In the path that shows the relationship between the influence of knowledge on perceived benefits (X3 X2), the $\mathrm{p}$ value obtained is 0.000 with a $\mathrm{T}$ statistic of 6.083 and a positive path coefficient of 0.394 . Because the path $\mathrm{p}$ value $<0.05$, $\mathrm{T}$ statistic $>1.65$ and the path coefficient is positive, it can be concluded that customer knowledge about mobile banking applications has a positive and significant impact on perceived benefits, this indicates that the higher customer knowledge about the application mobile banking, the higher the customer's perception of the benefits of using mobile banking.

\section{4) Line $X 3 \rightarrow Y$}

In the path that shows the relationship of the influence of knowledge on decisions to use mobile banking (X3 Y), the $\mathrm{p}$ value obtained is 0.233 with a $\mathrm{T}$ statistic of 0.730 . Due to the path $\mathrm{p}$ value $>$ 0.05 , $\mathrm{T}$ statistic $<1.65$, it can be concluded that customer knowledge of mobile banking 
applications has no significant effect on customer decisions to use mobile banking, this indicates that customers with a lot of knowledge about mobile banking applications not necessarily decide to use a mobile banking application.

\section{5) Line $X 2 \rightarrow Y$}

In the path that shows the effect of perceived benefits on decisions to use mobile banking ( $\mathrm{X} 2 \mathrm{Y})$, the $\mathrm{p}$ value obtained is 0.002 with a $\mathrm{T}$ statistic of 2.887 and a positive path coefficient of 0.273 . Because the path $\mathrm{p}$ value $<0.05$, $\mathrm{T}$ statistic $>1.65$ and the path coefficient is positive, it can be concluded that customer perceptions of the benefits of mobile banking applications have a positive and significant impact on customer decisions to use mobile banking, this indicates that the higher customer perceptions of the benefits of mobile banking applications, the higher the customer's decision to use mobile banking.

\section{6) Line $X 4 \rightarrow X 5$}

In the path that shows the relationship between risk perception and customer trust (X4 X5), the p value obtained is 0.013 with a $\mathrm{T}$ statistic of 2.220 and a negative path coefficient of -0.174 . Because the path $\mathrm{p}$ value $<0.05$, $\mathrm{T}$ statistic $>1.65$ and the path coefficient is negative, it can be concluded that risk perception has a negative and significant effect on customer trust, this indicates that the higher customer perceptions of the risk of using mobile banking, it will reduce customer confidence in the mobile banking application

\section{7) Line $X 4 \rightarrow Y$}

In the path that shows the relationship between risk perception and the decision to use mobile banking ( $\mathrm{X} 4 \mathrm{Y}$ ), the $\mathrm{p}$ value obtained is 0.001 with a $\mathrm{T}$ statistic of 3.113 and a negative path coefficient of 0.215 . Because the path $\mathrm{p}$ value $<0.05$, $\mathrm{T}$ statistic > 1.65 and the path coefficient is negative, it can be concluded that customer perceptions of the risk of using mobile banking applications have a negative and significant effect on customer decisions to use mobile banking. The higher the customer's perception that the use of mobile banking has a high risk, the lower the customer's decision to use mobile banking.

\section{8) Line $X 6 \rightarrow X 5$}

In the path that shows the relationship between security perceptions and customer trust (X6 X5), the $\mathrm{p}$ value obtained is 0.000 with a $\mathrm{T}$ statistic of 18.302 and a positive path coefficient of 0.697 . Because the path $\mathrm{p}$ value $<0.05$, $\mathrm{T}$ statistic $>1.65$ and the path coefficient is positive, it can be concluded that the security of using mobile banking has a negative and significant effect on customer trust, this indicates that the higher the security of the mobile banking application, the higher the security of the mobile banking application. the higher the customer trust in the mobile banking application

\section{9) Line $X 6 \rightarrow Y$}

In the path that shows the relationship between the influence of security on the decision to use mobile banking (X6 Y), the $\mathrm{p}$ value obtained is 0.218 with a T statistic of 0.781 . Due to the path $\mathrm{p}$ value $>0.05$, $\mathrm{T}$ statistic $<1.65$, it can be concluded that security has no significant effect on customer decisions to use mobile banking, this indicates that customers who judge that this application is safe do not necessarily decide to use mobile banking. .

\section{0) Line $X 5 \rightarrow Y$}

In the path that shows the relationship between perceived benefits of using mobile banking ( $\mathrm{X} 5 \mathrm{Y}$ ), the $\mathrm{p}$ value obtained is 0.034 with a $\mathrm{T}$ statistic of 1.826 and a positive path coefficient of 0.197 . Because the path $\mathrm{p}$ value $<0.05$, $\mathrm{T}$ statistic $>1.65$ and the path coefficient is positive, it can be concluded that customer trust in mobile banking applications has a positive and significant effect on customer decisions to use mobile banking, this indicates that the higher the trust customers towards mobile 
banking applications, the higher the customer's decision to use mobile banking.

Coefficient of Determination

\begin{tabular}{ccc}
\multicolumn{3}{c}{ Table 4: R Square } \\
\hline & R Square & R Square Adjusted \\
\hline X2 & 0.498 & 0.492 \\
\hline X5 & 0.476 & 0.469 \\
\hline Y & 0.536 & 0.517 \\
\hline
\end{tabular}

The results of the analysis show that the adjusted $\mathrm{R}$ square value of the perceived benefit variable (X2) is 0.492 , this shows that $49.2 \%$ of customers' perceptions of the benefits of mobile banking are influenced by perceptions of convenience and customer knowledge about mobile banking applications, while there are still $50.8 \%$ of customers' perceptions of the ease of use of mobile banking are influenced by other factors other than these two factors.

Furthermore, on the trust construct, the adjusted $\mathrm{R}$ square value of the trust construct model is 0.469 , this shows that
$46.9 \%$ of customer trust in the lobby banking application is influenced by customer perceptions of the risks of using mobile banking and customer perceptions of security using mobile banking, while there are still as many as $53.1 \%$ of customers' trust in using mobile banking is influenced by other factors other than these two factors.

Furthermore, in the decision construct to use mobile banking, the $\mathrm{R}$ square value obtained is 0.517 , this shows that $51.7 \%$ of customers' decisions to use mobile banking are influenced by customer perceptions of the ease of mobile banking applications, application benefits, customer knowledge about mobile banking applications, customer perceptions of the risks of using mobile banking, customer trust in mobile banking applications and customer perceptions of the security of using mobile banking, while the remaining $48.3 \%$ of customers' decisions to use mobile banking are influenced by other factors other than these six factors.

\section{Indirect Influence}

\begin{tabular}{lccccc}
\multicolumn{7}{c}{ Table 5: Indirect Test Result } \\
\hline & $\begin{array}{c}\text { Original } \\
\text { Sample } \\
(\mathbf{O})\end{array}$ & $\begin{array}{c}\text { Sample } \\
\text { Mean (M) }\end{array}$ & $\begin{array}{c}\text { Standard } \\
\text { Deviation } \\
(\text { STDEV) }\end{array}$ & $\begin{array}{c}\text { T Statistics } \\
(\mid \mathbf{O} / \text { STDEV } \mid)\end{array}$ & P Values \\
\hline $\mathbf{X 3}->$ X2 $>$ Y & 0.107 & 0.107 & 0.040 & 2.699 & $\mathbf{0 . 0 0 4}$ \\
\hline $\mathbf{X} 4->$ X5 $->$ Y & -0.034 & -0.034 & 0.027 & 1.264 & $\mathbf{0 . 1 0 3}$ \\
\hline $\mathbf{X 6}->$ X5 $->$ Y & 0.137 & 0.132 & 0.074 & 1.857 & $\mathbf{0 . 0 3 2}$ \\
\hline $\mathbf{X} 1->$ X2 $>$ Y & 0.110 & 0.110 & 0.041 & 2.702 & $\mathbf{0 . 0 0 4}$ \\
\hline
\end{tabular}

1. $\mathrm{X} 1 \rightarrow \mathrm{X} 2 \rightarrow \mathrm{Y} \mid \mathrm{P}$ value $<0.05$ and $\mathrm{T}$ statistic > 1.65: Perception of benefits can mediate the indirect effect of Perception of Ease to use on decisions to use mobile banking. This means that the higher the customer's perception of the ease of using mobile banking, the higher the customer's perception of the benefits of using the mobile banking application, which in turn will increase the customer's decision to use mobile banking.

2. $\mathrm{X} 3 \rightarrow \mathrm{X} 2 \rightarrow \mathrm{Y} \mid \mathrm{P}$ value $<0.05$ and $\mathrm{T}$ statistic > 1.65: Perception of benefits can mediate the indirect effect of customer knowledge on decisions to use mobile banking. This means that the higher the customer's knowledge of the mobile banking application, the higher the customer's perception of the benefits of using the mobile banking application, which in turn will increase the customer's decision to use mobile banking.

3. $\mathrm{X} 4 \rightarrow \mathrm{X} 5 \rightarrow \mathrm{Y} \mid \mathrm{P}$ value $<0.05$ and $\mathrm{T}$ statistic $>1.65$ :Trust is not influenced by the perception of risk on the customer's decision to use mobile banking. This is because the influence of risk perception on customer decisions to use mobile banking is very strong so that without being mediated by customer 
trust, risk perception will definitely reduce customer decisions to use mobile banking applications.

4. $\mathrm{X} 6 \rightarrow \mathrm{X} 5 \rightarrow \mathrm{Y} \mid \mathrm{P}$ value $<0.05$ and $\mathrm{T}$ statistic > 1.65:Customer trust can mediate the indirect effect of customer perceptions of security of use on decisions to use mobile banking. This means that the higher the customer's perception of the security of mobile banking, the higher the customer's trust in the mobile banking application, which in turn will increase the customer's decision to use mobile banking.

\section{Hypotheses Testing}

\begin{tabular}{|c|c|c|c|}
\hline & Hypothesis & Original Sample (0) & $\begin{array}{l}\text { Conclusion } \\
\end{array}$ \\
\hline (1) & $\begin{array}{l}\text { Perception of Ease to use has a } \\
\text { positive effect on perception of } \\
\text { benefits }\end{array}$ & $\begin{array}{l}\text { - } \text { Path Coef }=0,402 \\
\text { - } \text { T Statistics }=6,303 \\
\text { - } \text { P value }=0,000\end{array}$ & (accepted) \\
\hline (2) & $\begin{array}{l}\text { Perception of ease to use has a } \\
\text { positive and significant effect on } \\
\text { decisions to use mobile banking }\end{array}$ & $\begin{array}{l}\text { - } \text { Path Coef }=0,208 \\
\text { - } \text { T Statistics }=2,433 \\
\text { - } \text { P value }=0,008\end{array}$ & (accepted) \\
\hline (3) & $\begin{array}{l}\text { Knowledge has a positive and } \\
\text { significant effect on perception of } \\
\text { benefits }\end{array}$ & $\begin{array}{l}\text { - } \text { Path Coef }=0,394 \\
\text { - } \text { T Statistics }=6,083 \\
\text { - } \quad \text { P Value }=0,000\end{array}$ & (accepted) \\
\hline (4) & $\begin{array}{l}\text { Knowledge has a positive and } \\
\text { significant effect on decisions to use } \\
\text { mobile banking }\end{array}$ & $\begin{array}{l}\text { - } \text { Path Coef }=0,068 \\
\text { - T Statistics }=0,730 \\
\text { - } \text { P Value }=0,233\end{array}$ & (rehected) \\
\hline (5) & $\begin{array}{l}\text { Perception of benefit has a positive } \\
\text { and significant effect on decisions to } \\
\text { use mobile banking }\end{array}$ & $\begin{array}{l}\text { - } \text { Path Coef }=0,273 \\
\text { - } \text { T Statistics =2,887 } \\
\text { - } \quad \text { P Value }=0,002\end{array}$ & (accepted) \\
\hline (6) & $\begin{array}{l}\text { Risk perception has a negatif and } \\
\text { significant effect on decisions to use } \\
\text { mobile banking }\end{array}$ & $\begin{array}{l}\text { - } \text { Path Coef }=-0,174 \\
\text { - T Statistics }=2,220 \\
\text { - } \quad \text { P Value }=0,013\end{array}$ & (accepted) \\
\hline (7) & $\begin{array}{l}\text { Risk perception has a negatif and } \\
\text { significant effect on trust }\end{array}$ & $\begin{array}{l}\text { - } \text { Path Coef }=-0,215 \\
\text { - T Statistics }=3,113 \\
\text { - } \text { P Value }=0,001\end{array}$ & (accepted) \\
\hline (8) & $\begin{array}{l}\text { Secutity has a positive and } \\
\text { significant effect on decisions to use } \\
\text { mobile banking }\end{array}$ & $\begin{array}{l}\text { - } \text { Path Coef }=0,697 \\
\text { - } \text { T Statistics }= \\
18302 \\
\text { - } \text { P Value }=0,000\end{array}$ & (accepted) \\
\hline (9) & $\begin{array}{l}\text { Secutity has a positive and } \\
\text { significant effect on trust }\end{array}$ & $\begin{array}{l}\text { - } \text { Path Coef }=0,081 \\
\text { - } \text { T Statistics }=0,781 \\
\text { - } \text { P Value }=0,218\end{array}$ & (rehected) \\
\hline (10) & $\begin{array}{l}\text { Trust has a positive and significant } \\
\text { effect on decisions to use mobile } \\
\text { banking }\end{array}$ & $\begin{array}{l}\text { - } \text { Path Coef }=0,197 \\
\text { - } \text { T Statistics }=1,826 \\
\text { - } \text { P Value }=0,034\end{array}$ & (accepted) \\
\hline
\end{tabular}

\section{CONCLUSION}

1. Perception of ease of use has a positive and significant effect on perception of benefits, this indicates that the higher the customer's perception of the ease of using mobile banking, the higher the customer's perception of the benefits of using mobile banking.

2. Customer perceptions of the ease of use of mobile banking applications have a positive and significant effect on customer decisions to use mobile banking, this shows that the higher the customer's perception of the ease of use of the mobile banking application, the higher the customer's decision to use mobile banking.

3. Customer knowledge about mobile banking applications has a positive and significant effect on perceptions of benefits, this shows that the higher customer knowledge about mobile banking applications, the higher customer perceptions of the benefits of using mobile banking.

4. Customer knowledge of mobile banking applications does not have a significant effect on customer decisions to use mobile banking, this shows that customers with a lot of knowledge about mobile banking applications do not necessarily decide to use mobile banking applications.

5. Customer perceptions of the benefits of mobile banking applications have a positive and significant impact on customer decisions to use mobile banking, this shows that the higher the customer's perception of the benefits of mobile banking applications, the higher the customer's decision to use mobile banking.

6. Risk perception has a negative and significant effect on customer trust, this indicates that the higher the customer's perception of the risk of using mobile banking, the lower the customer's trust in the mobile banking application.

7. Customer perception of the risk of using mobile banking applications has a negative and significant effect on customer decisions to use mobile banking, this shows that the higher the customer's perception that the use of mobile banking has a high risk, the lower the customer's decision to use mobile banking.

8. The security of using mobile banking has a positive and significant effect on customer trust, this shows that the higher the security of the mobile banking application, the higher the 
customer trust in the mobile banking application.

9. Security does not have a significant effect on customer decisions to use mobile banking, this shows that customers who judge that this application is safe do not necessarily decide to use mobile banking.

10. Customer trust in mobile banking applications has a positive and significant effect on customer decisions to use mobile banking, this shows that the higher customer trust in mobile banking applications, the higher customer decisions in using mobile banking.

\section{REFERENCES}

1. Almousa, M. (2014). The Influence of Risk Perception in Online Purchasing Behavior: Examination of an Early-Stage Online Market. International Review of Management and Business Research, 3(2), 779-787.

2. Al-Shomali, SA, Gholami, R and Clegg, B 2008, „Internet Banking Ac-ceptance in the Context of Developing Countries : An Extension of the Technology Acceptance Model $^{e c}$, Operation and Information Management Group, Aston Business School, Birmingham B47ET, UKl, hal. 1-16.

3. Ahmad, \& Pambudi, B. S. (2014). Pengaruh Persepsi Manfaat, Persepsi Kemudahan, Keamanan dan Ketersediaan Fitur Terhadap Minat Ulang Nasabah Bank Dalam Menggunakan Internet Banking. Jurnal Studi Manajemen.

4. Amijaya,G.R. 2010. Pengaruh Persepsi Teknologi Informasi, Kemudahan, Resiko, dan Fitur Layanan Terhadap Minat Ulang Nasabah Bank Dala Menggunakan Internet Banking. Jurnal Manajemen. Universitas Diponegoro.

5. Andayani, N., Modding, B., \& Mahmud, A. (2020). Pengaruh Persepsi, Layanan Dan Keamanan Sistem Terhadap Minat Nasabah Menggunakan Aplikasi Mobile Banking. Tata Kelola, $7(2)$. https://doi.org/10.52103/tatakelola.v7i2.169

6. Al-Rawad, M. I., Al Khattab, A., AlShqairat, Z. I., Krishan, T. A., \& Jarrar, M. H. (2015). An Exploratory Investigation of Consumers' Perceptions of the Risks of
Online Shopping in Jordan. International Journal of Marketing Studies, 7(1), p157.

7. Amin, S., \& Mahasan, S. S. (2014). Relationship Between Consumers Perceived Risks and Consumer Trust: A Study of Sainsbury Store. Middle-East Journal of Scientific Research, 19(5), 647-655.

8. Ariaya, Arief. (2020). Tantangan\&Peluang Bank dalamMembiayain Making Indonesia 4.0 dan PaskaPandemi. Virtual Seminar LPPI ke-33. November 2020. Jakarta

9. Arslanian, Henri and Fabrice Fischer, 2019. The Future of Finance. The Impact of Fintech, AI, and Crypto on Financial Services. Palgrave Macmillan.

10. Bank Indonesia. 2014. Bank Indonesia Mencanangkan Gerakan Nasional Non Tunai.http://www.bi.go.id/id/ruangmedia/siaranpers/Pages/sp_165814.aspx

11. Baridwan, Zaki, 1992. Intermediate Accounting, Edisi Ketujuh, Yogyakarta: BPFE.

12. Batunanggar, S. 2020. Fintech, the Future of Finance and new Regulatory Framework. KuliahUmum Virtual-MM USU, 27 Oktober 2020.

13. Belanger, F., et.al. 2002. „Trustworthiness in Electronic commerce: The Role of Privacy, Security, and Site Attributes"e. Strategic Information Systems, 11, 245-270.

14. Budi Rahardjo. 2005. Keamanan Sistem Informasi Berbasis Internet. Bandung: PT Insan Infonesia

15. Bulkia, S., Herawati, A. S., \& Hasanah, N. (2019). Pengaruh Pengetahuan Nasabah Dan Kualitas Layanan Terhadap Minat Individu Pengguna Internet Banking Banjarmasin. At-Tadbir: Jurnal Ilmiah Manajemen, 3(2). https://doi.org/10.31602/atd.v3i2.1873

16. Bazgosha, G., Eizi, N., Nawaser, K., \& Parhizgar, M. M. (2012). Technology of Ebanking: Perspective of Costumers' Perceived Risk and Uncertainty. Indian Journal of Science and Technology, 5(2), 2200-2208

17. Bhatti, T. (2007). Exploring Factors Influencing the Adoption of Mobile Commerce. Journal of Internet Banking and Commerce, Vol.12, No.3

18. Cheong, W.O., Park, M.H., Kang, W.K., Joung, H.K., and Seo, Y.J. 2005. Determination of Catechin Compounds in Korean Green Tea Infusions under Various Extraction Conditions by High Performance 
Liquid Chromatography. Bull. Korean Chem. Soc. Vol. (26) : No.5 :747. Incheon.

19. Cita Melasari. (2018). Pengaruh Kepercayaan, Kegunaan, Kemudahan, Privacy Risk, Time Risk, Dan Financial Risk Terhadap Minat Penggunaan Mobile Banking Bank Muamalat. Performance, 25(1).

20. Darmawan, D. (2019). Pengaruh pengetahuan nasabah, teknologi informasi, kepercayaan dan mutu e-banking informasi, kepercayaan dan mutu e-banking terhadap minat bertransaksi online terhadap minat bertransaksi online (studi kasus nasabah $b$. Journal of Chemical Information and Modeling, 53(9).

21. Davis, Fred D. 1989. Persepsi kegunaan, persepsi kemudahan penggunaan, dan penerimaan teknologi informasi. MIS Quarterly : 319-340

22. Dewi, Ni Made A. P., dan I Gde Kt. Warmika. 2016. Peran Persepsi Kemudahan Penggunaan, Persepsi Manfaat dan Persepsi Resiko Terhadap Niat Menggunakan Mobile Commerce di Kota Denpasar. E-Jurnal Manajemen Universitas Udayana, Vol. 5, No. 4: 2606-2636

23. Dewi, S., Sabri, S., \& Winata, V. P. (2018). Analisis Kemudahan Penggunaan, Efisiensi dan Keamanan Terhadap Minat Nasabah Bertransaksi Menggunakan BSM Mobile Banking Pada Bank Syariah Mandiri Kantor Cabang Payakumbuh. EKONOMIKA SYARIAH: Journal of Economic Studies, 2(2). https://doi.org/10.30983/es.v2i2.723

24. Dionisius Patu Yuda Aestetika, Analisis Faktor-faktor yang Mempengaruhi Minat Nasabah Bertransaksi Internet Banking Panin Cabang Pandanaran Semarang, Magister Manajemen, Universitas Diponegoro, 2014.

25. Dwitasari, Marisca dan Baridwan, Zaki. 2014. Faktor Determinan Minat Individu Menggunakan M-Commerce: Technology Acceptance

26. Dowling, G.R., dan Staelin, R., (2001). A Model of Perceived Risk and Intended RiskHandling Activity, Journal of Consumer Research, Vol. 21

27. Durmus, B., Erdem, Y. C., Ozcam, D. S., \& Akgun, S. (2015). Exploring Antecedents of Private Shopping intention: The Case of Turkish Apparel Industry. European Journal of Business and Management, 7(12), 64-77.
28. Elida Florentina Sinaga Simanjorang, H. C. (2019). faktor-faktor yang mempengaruhi keputusan nasabah menggunakan layanan internet banking PT. Bank Mestika rantauprapat. ecobisma (jurnal ekonomi, bisnis dan manajemen), 3(1). https://doi.org/10.36987/ecobi.v3i1.693

29. Fadhilatul Fitri, Pengaruh Pengetahuan Nasabah, Teknologi Informasi, Kepercayaan dan Mutu E-Banking terhadap minat bertransaksi online, (Lampung: Skripsi tidak diterbitkan, 2016)

30. Fahmi, Irham 2014. PengantarPerbankan. Teori\&Aplikasi. PenerbitAlfabeta, Bandung

31. Fauzy, T. O., Purwadi, A., \& Hakim, R. (2019). Analisis Pengetahuan tentang Perbankan Syariah Santri Pondok Pesantren Al-Ittihad Mojokerto dan Pengaruhnya terhadap Minat Menabung di Bank Syariah. Iqtishodia: Jurnal Ekonomi Syariah, 4(2). https://doi.org/10.35897/iqtishodia.v4i2.230

32. Febrianti, N. (2020). Analisis Dimensi Persepsi yang Mempengaruhi Minat Nasabah dalam Menggunakan Aplikasi Mobile Banking (Studi Kasus Pada BJB Syariah KCP Ciputat). Skripsi, 21(1).

33. Fitri,fadhilatul. $2016 . \quad$ "pengaruh pengetahuan nasabah, teknologi informasi, kepercayaan dan mutu E-Banking terhadap minat bertransaksi online (studi kasus nasabah BNI Syariah Medan)", tesis sarjana : Program Studi Ekonomi Islam : Medan.

34. Fitriana, A. (2016). Analisis TAM TerhadapFaktor-Faktor yang Mempengaruhi Nasabah MenggunakanLayanan Internet Banking BCA. CSRID (Computer Science Research and Its Development Journal), 7(3). $\quad$ https://doi.org/10.22303/csrid.7.3. 2015.135-144

35. Gu, J. C., Lee, S. C., \& Suh, Y. H. (2009). Determinants of Behavioral Intention to Mobile Banking. https://doi.org/10.1287//mnsc,35.8.982

36. Gurung, Anil. 2006. Empirical Investigation of the Relationship of Privacy Socurity, and Trust with Behavioral Intention to Transact in E-Commerce. The University Of Texas at Arlingo

37. Gutter, M. S., \& Copur, Z. (2011). Financial Behaviors and Financial Well-Being of College Students : Evidence from a National Survey. Journal of Family and Economic Issues, 32, 699-714. https://doi.org/10.1007/s10834-011- 9255-2 
38. Handaya, Agus Dwi. (2019). TantangandalammembangunKompetensi\& Skill di Era Industri 4.0. KulianUmumdi ProgramMgisterManajemen, USU

39. Hapsara, Radityo Febri. 2015. "Pengaruh Kegunaan, Kemudahan, Resiko dan Kepercayaan Terhadap Penggunaan Mobile Banking (Studi Pada Nasabah Bank Bri Kantor Cabang Solo Kartasura)". Skripsi. Program Studi Akuntansi Fakultas Ekonomi dan Bisnis Universitas Muhammadiyah Surakarta.

40. Harlan, Dwimasta. 2014. "Pengaruh Kemudahan, Kepercayaan Dan Risiko Persepsian Terhadap Bertransaksi Menggunakan EBanking Pada UMKM Di Kota Yogyakarta". Skripsi. Fakultas Ekonomi Universitas Negeri Yogyakarta.

41. Hasibuan, M. 2003. Organisasi dan Motivasi Dasar Peningkatan Produktivitas. Jakarta: Bumi Aksara

42. Hyun Shik Yoon dan Luis Occena 2014. "Impacts of Customers Perceptions on Internet Banking Use with a 15 Smart Phone". Economic Sciences Series. Journal of Business and Economic. Vol. 1

43. Ida, \& Dwinta, C. Y. (2010). Pengaruh Locus of Control, Financial Knowledge, Income Terhadap Fiancial Management Behavior. Jurnal Bisnis Dan Akuntansi, 12(3), 131-144.

44. Infobank. Analisis-Strategi Perbankan \& Keuangan. No. 490. April 2019.Vol.XLI, No. 492, Mei 2019, Vol. XLI, No. 514 Februari 2021. Vol XLII, No515 Maret 2021 Vol XLIII dan No. 516 April 2021 Vol. XLIII

45. IkatanBankir Indonesia, 2015. Memahami Bisnis Bank. Modul Sertifikasi Tingkat-I General Banking. Edisi ke-2 Cetakan ke-4. Penerbit PT. Gramedia Pustaka Utama, Jakarta.

46. Imam Ghozali, 2001. Aplikasi Multivariat dengan Program SPSS. Badan Penerbit Universitas Diponegoro

47. Islam, S. M. et al. 2011. Disaster in Bangladesh and Management with Advanced Information System, Disaster Prevention and Management, Vol. 20

48. Imam Sugih Rahayu, "Minat Nasabah Menggunakan Mobile Banking Dengan Menggunakan Kerangka Technology Acceptance Model" (Skripsi, Perbankan Syariah, Yogyakarta, 2015), h. 1.
49. Jayantari, I. A. A. U., \& Seminari, N. K. (2018). Peran Kepercayaan Memediasi Persepsi Risiko Terhadap Niat Menggunakan Mandiri Mobile Banking Di Kota Denpasar. E-Jurnal Manajemen Universitas Udayana, 7(5). https://doi.org/10.24843/ejmunud.2018.v07. i05.p13Kajian pustaka.2012.Teori Persepsi. http://www.kajianpustaka.com/2012/10/teor i-pengertian-proses-faktor-persepsi. $\mathrm{Html}$. Diakses pada tanggal 16-03-2015 pukul 16.03 WIB

50. King, Brett. 2020. Bank 4.0. Perbankan di Mana Saja dan Kapan Saja. TidakPerlu di Bank. Cetakan - II. Mahaka Publishing, Jakarta.

51. Kholid, F. I. (2018). Analisis Pengaruh Keamanan, Kemudahan Penggunaan, Kepercayaan Nasabah dan Kebermanfaatan Terhadap Minat Menggunakan E-Banking Pada PT Bank BNI Syariah KCP Magelang. Jurnal Sains Ekonomi Dan Perbankan Syariah, 8(2).

52. Kieso, Donald E, Jery J. Weygandt dan Tery D. Warfield. 2007. Accounting Principles, Edisi 12 by: Salemba Empat

53. Kuncoro, M \& Suhardjono. 2002 Manajemen Perbankan. Jakarta: Divisi Buku Perguruan Tinggi PT RajaGrafindo Persada. Kuncoro, M \& Suhardjono. 2002

54. Koufaris, Marios dan Sosa, William Hampton. 2002. "Customer Trust Online: Examining The Role of The Experience with The Website", CIS Working Paper Series, May 2002.

55. Koufaris, Marios. 2002."Applying the Technology Acceptance Model and Flow Theory to Online Consumer Behavior". Information Systems Research, Journal Volume Forthcoming, 2002.

56. Laksana, G. b., Astuti, E. S., dan Dewantara, R. Y. 2015. Pengaruh Persepsi Kemanfaatan, Persepsi Kemudahan Penggunaan, Persepsi Resiko dan Persepsi Kesesuaian Terhadap Minat Menggunakan Mobile Banking. Jurnal Administrasi Bisnis (JAB). Vol.26 No.2

57. Law, K. 2007. Impact of Perceived Security on Conumer Trust in Online Banking. Disertasi yang tidak diterbitkan. AUT University. Auckland, New Zealand

58. Lenggogeni, S. (2015). Travel risk perceptions, travel intentions and influencing factors: A natural disaster context. 
59. Maharani, T. N. (2016). Pengaruh Personal Financial Literacy, Financial Attitude Terhadap Financial Management Behavior Mahasiswa S1 Fakultas Ekonomi Universitas Andalas. Skripsi. Universitas Andalas.

60. Mahardika Aditya Widjana dan Basuki Rachmat. 2011. "Factors Determining Acceptance Level of Internet Banking Implementation". Journal of Economics, Business and Accountancy Ventura Volume 14, No. 2. (Agustus). Pp 161-174.

61. Maharsi, Sri dan Fenny. 2006. "Analisa Faktor-

faktor yang Mempengaruhi Kepercayaan dan Pengaruh Kepercayaan Terhadap Loyalitas Pengguna Mobile banking di Surabaya". Jurnal Akuntansi dan Keuangan, Vol. 8 (1), Mei 2006, 35-51.

62. Mien, N. T. N., \& Thao, T. P. (2015). Factors Affecting Personal Financial Management Behaviors: Evidence from Vietnam. Proceedings of the Second AsiaPacific Conference on Global Business, Economics, Finance and Social Sciences (AP15Vietnam Conference), 10-12.

63. Miller, Roger LeRoy and Robert W. Pilsinelli. 1985. Modern Money and Banking. Mc.Graw-Hill, Inc.

64. Mohamed, N. A. (2017). Financial Socialization: A Cornerstone for Young Employees' Financial Well-Being. Reports on Economics and Finance, 3(1), 15-35. https://doi.org/https://doi.org/10.12988/ref.2 017.711

65. Morgan, R.M. and Hunt, S.D. (1994), "The commitment-trust theory of relationship marketing", Journal of Marketing, Vol. 58 No. 3, pp. 20-38.

66. Muir, K., Hamilton, M., J.H, M., A., S., \& Saunders, P. (2017). Exploring Financial Wellbeing In The Australian Context. Australia. Nababan, D., \& Sadalia, I. (2012). Analisis Personal Financial Literacy Dan Financial Behavior Mahasiswa Strata I Fakultas Ekonomi Universitas Sumatra Utara. Universitas Sumatra Utara, 1-16.

67. Mukherjee, A dan Nath, P. 2003. „A Model of Trust in Online Relationship Bankingee. International Journal of Bank Marketing, Vol.21, No. 1, 5-15.

68. Munawir. S. 2001. Akuntansi Keuangan dan Manajemen. Edisi Pertama. Penerbit BPFE:Yogyakarta.
69. Nielsen, J. (2001). Success Rate: The Simplest Usability Metric. ( https://www.nngroup.com/articles/successrate-the-simplest-usability- metric/)

70. Nisa, F., Rozza, S., \& Muchtar, A. M. (2020). Peran Public Relations, Kepercayaan, Dan Persepsi Kemudahan Dalam Mendorong Minat Bertransaksi Menggunakan Mobile Banking (Studi Kasus Pengguna Mobile Banking BNI Syariah di Kota Depok). Account, 7(1). https://doi.org/10.32722/acc.v7i1.2839

71. Parrotta, J. L., \& Johnson, P. J. (1998). The Impact of Financial Attitudes and Knowledge on Financial Management and Satisfaction of Recently Married Individuals. Financial Counseling and Planning, 9(2).

72. Pavlou, Fred, (2001), "Perceived Usefulnes, Perceived Ease of Use and User Acceptance of Information Technology", MIS Quarterly, September

73. Pranoto, M. O., \& Setianegara, R. G. (2020). Analisis Pengaruh Persepsi Manfaat, Persepsi Kemudahan, Dan Keamanan Terhadap Minat Nasabah Menggunakan Mobile Banking (Studi Kasus pada PT Bank Rakyat Indonesia (Persero) Tbk Kantor Cabang Semarang Pandanaran). KEUNIS, $8(1)$. https://doi.org/10.32497/keunis.v8i1.2117

74. Pratiwi, Devvy Pisheila. (2012). Pengaruh Persepsi Manfaat, Persepsi Kemudahan dan Pengalaman Terhadap Perilaku Penggunaan Mobile banking dengan Dimediasi Niat Penggunaan Mobile banking Nasabah BCA di Surabaya. Skripsi. Sekolah Tinggi Ilmu Ekonomi Perbanas. Surabaya

75. Putri, D. L., \& Fithrie, S. (2019). Pengaruh Risiko, Manfaat dan Kemudahan Penggunaan Terhadap Kepercayaan Nasabah dalam Menggunakan Internet Banking di Pekanbaru (Studi Kasus pada Nasabah Bank Mandiri). Ikraith Ekonomika, 2(2).

76. Pinontoan, W. (2013). Pengaruh E-banking, Kualitas Pelayanan, Kualitas Komunikasi dan Kepercayaan Terhadap Loyalitas Nasabah pada Pt. Bank mandiri Cabang Manado. Jurnal EMBA, Vol 1, No(4).

77. Pousttchi, Key and Wiedemann G. Dietmar. 2011. What Influences Consumers' Intention to Use Mobile Payments?. Mobile Commerce Working Group, Chair of Buiness Informatics and System 
Engineering, University of Augsburg, Germany

78. Qamar, M. A. J., Khemta, M. A. N., \& Jamil, H. (2016). How Knowledge and Financial Self-Efficacy Moderate the Relationship between Money Attitudes and Personal Financial Management Behavior. European Online Journal of Natural and Social Sciences, 5(2), 296-308.

79. Rizky, N. (2018). Pengaruh Persepsi Kemudahan Penggunaan, Kepercayaan, Dan Pengetahuan Terhadap Minat Menggunakan E-Banking Dalam Bertransaksi Pada Umkm Di Kecamatan Buleleng. JIMAT (Jurnal Ilmiah Mahasiswa Akuntansi) Universitas Pendidikan Ganesha, 9(2).

80. Romadon, A. S., \& Nurhapsari, R. (2020). Pengaruh Kemudahan Terhadap Keputusan Menggunakan E-Banking Pada Bni 46 Kc Karangayu Semarang Dengan Minat Nasabah Dan Kepercayaan Sebagai Variabel Mediasi. Solusi, 18(4). https://doi.org/10.26623/slsi.v18i4.2847

81. Rukhviyanti, Y. W. A. R. \& N. (2015). Pengaruh Minat Individu Terhadap Penggunaan mobile banking (M-Banking): Model Kombinasi Technology Acceptance Model(Tam) Dan Theory Of Planned Behavior (TPB). Jurnal Informasi, VII(1).

82. Sadalia, Isfenti. 2019. Kesiapan Masyarakat MenghadapiTransformasiIndustriKeuangan dan Strategi Pengambilan Keputusan InvetasiKeuangan di Indonesia. Pidato PengukuhanJabatan Guru BESAR Tetapdalam Bidang IlmuManajemen Keuangan pada 5 Desember 2019. Universitas Sumatera Utara, Medan.

83. Saraswati dan Baridwan, Zaki. 2013. Penerimaan Sistem E-Commerce: Pengaruh Kepercayaan, Persepsi Manfaat dan Persepsi Risiko. JIMFEB. Volume 1. Nomor 2.

84. Sari, S., \& Tjini, A. (2013). Pengaruh Kepercayaan, Persepsi Kegunaan, Persepsi Kemudahan, dan Persepsi Kenyamanan terhadap Minat Penggunaan Sistem Internet Banking. Jurnal Ilmiah Universitas Brawijaya, 1 .

85. Saputro, B. D., \& Sukirno, S. (2013). Pengaruh Persepsi Kemudahan Penggunaan, Kepercayaan, Kecemasan Berkomputer Dan Kualitas Layanan Terhadap Minat Menggunakan Internet Banking. Nominal, Barometer Riset Akuntansi Dan
Manajemen, 2(1). https://doi.org/10.21831/nominal.v2i1.1647

86. Saputri, L. (2018). Pengaruh Persepsi Manfaat, Persepsi Kemudahan Penggunaan dan Persespi Risiko terhadap Minat Masyarakat Menggunakan Fasilitas Electronic Banking Bank Syariah dengan Kepercayaan sebagai Variabel Intervening. Journal of Chemical Information and Modeling, 53(9).

87. Selcuk, E. A. (2015). Factors Influencing College Students' Financial Behaviors in Turkey: Evidence from a National Survey. International Journal of Economics and Finance, 7(6), 87-94. https://doi.org/10.5539/ijef.v7n6p87

88. Sirat, A. H. (2010). Persepsi Masyarakat Terhadap Perbankan Syariah Di Kota Makassar the Perception of Makassar Community to Sharia Banking. Jurnal "AlQalam,"16(26).

89. Sundjaja, Inge Barlian. 2003. Manajemen Keuangan. Jakarta: Literata Lintas Media

90. Susanto, Andyka Rakhmad. 2013. Pengaruh Persepsi Kemudahan dan Persepsi Kemanfaatan Terhadap Penggunaan Youtube dengan Pendekatan TAM. Fakultas Ilmu Administrasi. Universitas Brawijaya. (Skripsi Tidak Terpublikasi).

91. Sulistiyarini, Suci. (2013). Pengaruh Minat Individu Terhadap Penggunaan Mobile banking: Model Kombinasi Technologi Acceptance Model (TAM) dan Theory Of Planned Behaviour (TPB). Jurnal Ekonomi. Universitas Brawijaya Malang.

92. Sun Zhang, 2011, Optimal VAr planning in area power system. International Conference on Power System Technology.

93. Sulistyarini, T. \& Susanti, M.L. 2013. Dukungan Keluarga Meningkatkan Kepatuhan Diet Pasien DM di Ruang Rawat Inap RS. Baptis Kediri. Jurnal STIKES.Vol.6, No.1.(1-10).

94. Soekidjo, Notoadmodjo, Metode Penelitian kesehatan, edisi revisi, (Jakarta, Rinneka cipta, 2010) hal 108

95. Syamsul Hadi Novi, Faktor-faktor yang Mempengaruhi Penggunaan Layanan Mobile Banking, skripsi, (Universitas Islam Indonesia, 2015), h. 58

96. Talika, F. T. (2016). Manfaat Internet Sebagai Media Komunikasi Bagi Remaja Di Desa Air Mangga Kecamatan Laiwui Kabupaten Halmahera Selatan. E-Journal, 5(1). 
97. Tjini, dan Baridwan. 2013. "Pengaruh Kepercayaan, Persepsi Kegunaan, Persepsi Kemudahan, dan Persepsi kenyamanan terhadap minat menggunakan Internet Banking”. Jurnal Akuntansi Universitas Diponegoro Semarang.

98. Utama, AriefMulya. 2020. The Role of Data Infrastructure for Industry 4.0. Virtual Seminar LPPI ke-33. November 2020. Jakarta.

99. Vankatesh, V. Morris et al. (2003). User Acceptance of Information Technology: Toward aUnified View.MIS Quartely. Vol. 27 No. 3: Hal 425-47

100. Widiyasari, R., \& Achadiyah, B. N. (2019). Computer Anxiety, Computer SelfEfficacy dan Perceived Usefulness oleh Pelaku UMKM. Jurnal Akuntansi Aktual, 5(3).https://doi.org/10.17977/um004v5i320 $19 \mathrm{p} 2031$

101. Yanuardinda, Cornezzia 2014. Analisis Determinan Minat Keperilakuan Dalam Menggunakan Mobile Banking. Fakultas
Ilmu Administrasi. Universitas Brawijaya. (Skripsi Tidak Terpublikasi).

102. Yousafzai, S.Y., Pallister, J.G., dan Foxall, G.R. 2003. "A Proposed Model of E-Trust for ElectronicBanking”. Journal of Marketing. Pp.847-860

103. Zemtsov, A. A., \& Osipova, T. Y. (2015). Financial Wellbeing as a Type of Human Wellbeing: Theoretical Review. The European Proceedings of Social\&BehaviouralSciences,385-392

104. Bank mandiri.co.id

105. www.bi.go.id

How to cite this article: Amy Aulia Purba, Isfenti Sadalia, Chairul Muluk. SEM / PLS application for analysis of factors affecting customer's decision in using mobile banking at Bank Mandiri Medan Gunung Karakatau SubBranch. International Journal of Research and Review. 2022; 9(1): 399-411. DOI: https:// doi.org/10.52403/ijrr.20220147 